\title{
Studi Pemetaan Tipologi Konflik Di Kawasan Timur Tengah
}

\author{
Rio Sundari \\ Fakultas Ilmu Sosial dan Ilmu Politik, Universitas Islam Riau \\ Korespondensi : riosundari@soc.uir.ac.id
}

\begin{abstract}
Abstrak
Penelitian ini adalah sebuah upaya pemetaan tipologi konflik di Kawasan Timur Tengah. Fenomena konflik yang terjadi di Kawasan Timur Tengah bukanlah peristiwa baru, namun peristiwa ini sudah terjadi sejak lama. Misalnya konflik yang terjadi antara Palestina dan Israel, konflik ini sudah sangat lama terjadi dan sampai saat ini konflik ini belum selesai. Begitu jug dengan sederetan konflik lain baik konflik antar negara maupun konflik lain yang melibatkan suku yang ada di Kawasan ini. Perserikatan Bangsa-Bangsa (PBB) sebagai sebuah institusi internasional paling besar belum menunjukkan peran signifikan dalam konflik yang terjadi di Kawasan ini, sehingga konflik diselesaikan dengan kekalahan / kemunduran / kehancuran satu negara oleh negara lain. Banyaknya kepentingan negara-negara besar di Kawasan Timur Tengah menjadikan konflik di wilayah ini tidak pernah selesai bahkan selalu bertambah. Penelitian ini menggunakan pendekatan model penelitian kualitatif deskriptif dalam melakukan analisis permasalahan secara empiris. Pendekatan kualitatif yang digunakan dalam penelitian ini adalah jenis studi kepustakaan yang sumber datanya dianalisis dari buku dan jurnal terkait penelitian studi pemetaan tipologi konflik di Kawasan Timur Tengah. Temuan dalam penelitian ini menunjukkan bahwa ada beberapa tipologi konflik yang terjadi di Kawasan Timur Tengah yaitu konflik perebutan sumber minyak, konflik sosial politik, konflik ideologi. Tipologi ini secara garis besar yang menjadikan Kawasan Timur Tengah penuh dengan konflik.
\end{abstract}

Kata Kunci : Konflik, Tipologi, Timur Tengah

\begin{abstract}
This research is an attempt to map conflict typologies in the Middle East Region. The phenomenon of conflict that occurred in the Middle East Region is not a new event, but this event has been happening for a long time. For example, the conflict that occurred between Palestine and Israel, this conflict has been going on for a very long time and until now this conflict has not been completed. Likewise with a series of other conflicts, both conflicts between countries and other conflicts involving ethnic groups in this area. The United Nations (UN) as the largest international institution has not shown a significant role in the conflicts that occur in this region, so that conflicts are resolved with the defeat / decline / destruction of one country by another country. The many interests of major countries in the Middle East Region make conflicts in this region never end and even increase. This study uses a descriptive qualitative research model approach in analyzing the problem empirically. The qualitative approach used in this research is a type of literature study whose data sources are analyzed from books and journals related to the study of conflict typology mapping studies in the Middle East Region. The findings in this study indicate that there are several typologies of conflict that occur in the Middle East Region, namely conflicts over oil resources, socio-political conflicts, and ideological conflicts. This typology in general is what makes the Middle East region full of conflict.
\end{abstract}

Keywords: Conflict, Typology, Middle East 


\section{PENDAHULUAN}

Wilayah Timur Tengah adalah kawasan yang tidak pernah sepi dengan pemberitaan baik media lokal maupun media internasional. Ini karena Timur Tengah adalah kawasan yang penting dan strategis di dunia sehingga penuh dengan gejolak politik. Posisinya yang terhubung oleh benua Asia, Afrika dan Eropa menjadikan kawasan ini menjadi target untuk diperebutkan oleh aktor-aktor yang berkepentingan di dalamnya. Maka sangat wajar ketika seluruh dunia melabelkan wilayah Timur Tengah dengan wilayah panas yang sibuk dengan konflik yang tidak pernah usai.

Perseteruan konflik Palestina dan Israel misalnya, konflik yang sudah berlangsung lebih dari 70 tahun yang hingga saat ini belum terselesaikan. Antara tahun 2000 sampai 2005 saja tidak kurang dari 3.200 jiwa penduduk Palestina tewas dalam konflik tersebut (Mansbach \& Rafferty, 2008: 220). Data terakhir yang dirilis oleh Human Rights Watch $(H R W)$ pada tahun 2019, tercatat penduduk Palestina yang tewas mencapai 252 orang dan luka-luka sebanyak 25.522 orang akibat kebrutalan pasukan militer Israel (https://www.hrw.org/world-report/2019/country-chapters/israel/palestine). Data ini yang diambil dari beberapa tahun belakangan menunjukkan jumlah korban yang begitu besar, tentu akan jauh lebih besar jumlah korban yang tewas selama konflik antara Palestina dan Israel berlangsung sejak tahun 1948. Mirisnya konflik ini sampai saat ini masih belum terselesaikan dan selalu menimbulkan jumlah korban terus berjatuhan terutama masyarakat sipil Palestina.

Kemudian sejarah konflik yang tidak terlupakan di kawasan Timur Tengah adalah perang Irak dan Iran, di mana Irak menyerang Iran disebabkan oleh dominasi Iran sejak revolusi tahun 1979. Ada sebuah kekhawatiran ketika dominasi Iran di kawasan Timur Tengah akan membangkitkan semangat kaum Syi'ah Irak untuk memberontak pemerintah Irak yang dipimpin oleh Saddam Husein dikuasai dari Partai Ba'ath. Perseteruan antara Irak dan Iran terkait pencaplokan wilayah Khuzestan oleh Irak menjadi preseden yang menjadi sebab meletusnya perang tersebut.

Konflik di Suriah dan Yaman baru-baru ini menambah sederetan konflik di Timur Tengah. Konflik di Suriah meletus akibat adanya pemberontakan sekelompok masyarakat Suriah yang tidak suka dengan rezim Bashar Al-Assad. Pengaruh dari gelombang demokratisasi di Timur Tengah memicu gerakan demonstrasi dari kelompok masyarakat Suriah yang berujung pada pecahnya perang saudara. Munculnya Arab Saudi, Turki, Qatar, Iran, Rusia dan negara lainnya menambah konflik internal yang bermula pada tahuh 2011 ini beruntun panjang dan sengit (Tan and Perudin, 2019: 1).

Seperti konflik di Suriah, Yaman juga mengalami hal serupa yakni adanya pemberontakan terhadap pemerintahan yang sah oleh suku Houthi yang bersekutu dengan mantan Presiden Yaman Ali Abdullah Saleh. Data menunjukkan tidak kurang dari 100.000 jiwa tewas dalam konflik ini dan sekitar 10 juta jiwa mengalami krisis pangan. Sama seperti konflik Suriah, negara di luar Yaman seperti Arab Saudi, Iran, Uni Emirat Arab dan lain-lain juga ikut dalam konflik internal tersebut sehingga konflik justru semakin memanas. 


\section{METODE}

Penelitian ini menggunakan pendekatan model penelitian kualitatif deskriptif dalam melakukan analisis permasalahan secara empiris. Pendekatan kualitatif yang digunakan dalam penelitian ini adalah jenis studi kepustakaan yang sumber datanya dianalisis dari buku dan jurnal terkait penelitian studi pemetaan tipologi konflik di Kawasan Timur Tengah. Selanjutnya data dianalisis secara induktif dengan cara mengumpulkan berbagai artikel yang relevan dengan penelitian ini. Tahapan berikutnya adalah memberikan kesimpulan dari hasil penelitian yang menjadi temuan dalam penelitian ini.

\section{HASIL DAN PEMBAHASAN}

Secara historis, kehadiran wilayah Timur Tengah menjadi sangat penting bagi negara-negara yang memiliki kepentingan atasnya. Pergantian kekuasaan politik dari satu dinasti ke dinasti yang lain dan okupasi wilayah yang dilakukan oleh penguasa kepada wilayah lain menjadi pemandangan yang biasa. Dinamika ini menjadi bukti bahwa wilayah ini adalah penting dan strategis baik secara ekonomi maupun politik (Sahide, 2013: 139). Warisan konflik perebutan berbagai sumber daya yang ada di Timur Tengah, baik sumber daya ekonomi maupun politik sampai hari ini masih terjadi. Runtuhnya dinasti Ustmaniyah di Turki tahun 1924 sebagai penanda berakhirnya pergolakan politik dinasti-dinasti Islam yang memiliki kekuasaan politik dan penguasaan wilayah yang luas. Setidaknya ada tiga hal yang menyebabkan runtuhnya dinasti Utsmaniyah ini yakni munculnya konflik internal yang tidak mampu diselesaikan oleh penguasa dinasti Utsmaniyah, kedua, adanya serangan-serangan dari bangsa Eropa, dan ketiga, karena adanya gerakan makar politik Zionis dan Freemasonry terhadap dinasti Utsmaniyah. Runtuhnya dinasti Ustmaniyah tidak lantas menjadikan wilayah Timur Tengah menjadi aman, justru wilayah ini semakin memanas dan penuh dengan konflik berkepanjangan yang tidak usai. Secara umum konflik di kawasan Timur Tengah memiliki tipologi konflik yang bisa dibagi ke dalam beberapa macam, yaitu konflik perebutan sumber minyak, konflik sosial politik, dan konflik Ideologi.

\section{Konflik Perebutan Sumber Minyak}

Konflik yang terjadi di negara-negara di kawasan Timur Tengah telah memberikan guncangan pada perekonomian global, hal ini dapat kita lihat langsung pada kondisi di pasar modal dengan indikator naik turunnya indeks perdagangan saham gabungan pada seluruh bursa di dunia. Minyak merupakan komoditi utama yang ada di Timur Tengah. Hampir setiap negara di kawasan Timur Tengah memiliki komoditi minyak mulai dari Arab Saudi, Irak hingga negara-negara teluk seperti Uni Emirat Arab, Kuwait maupun Qatar. Arti Timur Tengah menjadi jauh lebih besar dengan adanya minyak tersebut, karena seperti diketahui minyak adalah bahan bakar utama dan paling diperlukan dalam peradaban industrial kontemporer.

Terlepas dari faktor-faktor lain hal itu sudah cukup untuk menjadikan Timur Tengah kawasan paling penting di dunia. Cadangan minyaknya yang telah terbukti adalah dua pertiga cadangan minyak dunia yang dikenal. Karena berbagai faktor eksploitasinya mudah dan biayanya rendah, sehingga produksi minyak Timur Tengah terus meningkat dengan cepat dan kini merupakan sekitar $45 \%$ produksi minyak dunia. Eropa Barat mendapatkan 70\% kebutuhan minyaknya dari kawasan itu dan Jepang bahkan 80\%. Dengan demikian dapat dikatakan bahwa negara-negara Eropa Barat dan Jepang bergantung pada Timur Tengah. Mengalirnya minyak dari kawasan itu secara bebas adalah soal mati hidup bagi kehidupan dan industri mereka. Dengan demikian Timur Tengah mempunyai potensi ekonomi dan politik yang besar. Minyak juga yang membuat negara-negara Timur Tengah menjadi kaya raya, karena cadangan minyak bumi di Timur Tengah mencapai 60\% dari cadangan minyak dunia (Burdah: 2008). 
Namun begitu, minyak juga yang membuat adanya sumber konflik di Timur Tengah. Salah satunya adalah konflik Iran dan Irak karena adanya minyak di perairan Shatt al-arab. Posisi laut Irak hanya berada di sebelah tenggara yang sangat sempit, yaitu dari garis pantai di Umm Qashr di Teluk Persia. Irak hanya memiliki akses laut sepanjang 19 KM. Pantai di teluk Persia merupakan satu-satunya akses laut yang dimiliki oleh negara Irak, sehingga pelabuhan yang berada di Basrah menjadi sangat penting bagi aktivitas perdagangan di Irak. Karena panjang garis pantai yang sedikit, Irak mengalami kesulitan mengekspor minyak melalui laut.

Keterbatasan akses laut tersebut menyebabkan Irak menjadi agresif serta berambisi menguasai "Shattal-Arab", sehingga menimbulkan konflik antara Irak dan Iran. Negara Iran bersikeras untuk mempertahankan wilayah tersebut setelah ditemukan sumberminya yang berada di Abadan. pada tahun 1975, Iran-Irak sepakat untuk menandatangani Perjanjian Aljiers yang membelah "Shatt al-Arab" bagi pelayaran Irak dan Iran, dengan imbalan Iran tidak akan menghasut atau membantu pemberontakan Suku Kurdi di Irak. Akan tetapi, perjanjian ini kemudian dicabut secara sepihak oleh Irak karena peristiwa "Revolusi Islam" di Iran. Akibat dari hal tersebut, kedua negara ini terlibat perang selama 8 tahun (19801988) (Sihbudi:1991).

Selain konflik dengan negara Iran, Irak memiliki konflik dengan negara Kuwait. Sebagai negara yang besar, Irak memiliki potensi untuk menginvasi negara tetangganya yang lebih kecil, yaitu Kuwait. Tepatnya pada tanggal 2 Agustus 1990 Irak melancarkan invasinya terhadap Kuwait. Hal tersebut tidak lain karena Irak ingin menambah luas pantainya, termasuk keberadaan dua pulau, yaitu Warbah dan Bubiyan, demi kelancaran kepentingan perdagangan minyak. Selain itu juga invasi AS ke Irak yang mana AS berusaha menguasai ladang minyak yang ada di daerah tersebut.

\section{Konflik Sosial Politik}

Suku - suku yang ada di Timur Tengah terdiri dari enam suku yaitu Arab, Yahudi, Parsi, Turki, Kurdi, Berber. Perbedaan sejatinya menyatukan antar suku-suku di timur tengah namun kenyataannya justru menimbulkan konflik. Salah satu konflik yang dari zaman kolonial sampai sekarang adalah konflik Arab - israel. Konflik ini dimulai semenjak berdirinya Israel pada tahun 1948 kemudian berlanjut ditahun 1967 dan hingga di tahun-tahun sekarang ini. Konflik yang juga mendapat perhatian publik cukup banyak adalah konflik antara suku Kurdi dengan suku Turki dan Arab. Kurdi merupakan suku yang unik karena suku ini bertempat di 3 suku lainnya yaitu Irak, Iran dan Turki. Oleh karenanya Kurdi juga bisa dikatakan suku nomaden. Kurdi ini juga berkeinginan menjadi negara Kurdistan supaya tidak ada lagi sebutan suku terjajah. Namun sayangnya, kehendak dari Kurdi selalu ditentang oleh banyak pihak hingga pada akhirnya suku ini sampai sekarang masih terlunta-lunta.

Selain masalah internal suku yang ada di Kawasan timur Tengah, masalah eksternal dari wilayah ini juga menambah catatan panjang konflik Timur Tengah. Bagian ini merupakan sesuatu yang tidak asing lagi karena sejak awal pembentukan nama Timur Tengah itu sudah merupakan konstruksi Inggris. Sebenarnya ada dua faktor yaitu internal dan eksternal. Keberhasilan Tunisia dan Mesir menjadi dorongan internal bagi negara-negara yang ingin melakukan aksi yang sama yang memang internal negara tersebut memiliki keinginan yang kuat untuk berubah. Dorongan eksternal adalah dorongan yang memang secara tersembunyi dilakukan oleh negara-negara yang memiliki kepentingan khusus bagi negara yang berkonflik. Hal ini memang perlu analisis yang mendalam tetapi menurut penulis, ada sebagian negara yang memang ada kepentingan Amerika untuk dapat memberikan pengaruh terhadap negara yang berkonflik agar Amerika mendapatkan keuntungan terutama dalam hal minyak bumi. Amerika Serikat,dengan bantuan sekutu regionalnya, menginvasi dan menghancurkan negara-negara tertentu di kawasan ini karena ingin membangun hegemoninya atas negara kaya minyak Timur Tengah. Semua petualangan imperialis Amerika harus didanai oleh uang pajak Amerika dan itu datang langsung dari gaji. Sayangnya, di bawah Presiden AS Barack Obama kami memiliki anggaran militer terbesar 
dalam sejarah kami. Kami berusaha untuk menghentikan agresi imperialis, dalam semua manifestasi yang berbeda.

\section{Konflik Ideologi}

Sebagai pusat perkembangan agama dunia Timur Tengah memiliki khasanah pemikiran keagamaan yang sangat kompleks. Namun dalam dalam batas tertentu, sejarah perkembangan politik keagamaan di timur tengah di warnai oleh gejala konflik dari tingkat yang kontruktif sampai tingkat destruktif. Ideologi keagamaan yang menampakkkan gejala konflik dalam abad 20 adalah mazhab besar islam yakni sunni dan syi'ah dan juga suku Yahudi. Konflik antara dua mazhab ini sudah pernah terjadi di era Ali bin Abu Thalib namun baru di tahun 2014 konflik ideologi yaitu antara Arab Saudi yang mewakili Sunni dan Iran yang mewakili Syiah berkembang. Konflik ini bermula ketika Arab Saudi berusaha mengkafirkan Syiah karena tidak sesuai dengan kaidah Islam. Konflik Yahudi dengan Islam lebih kepada konflik Arab dengan Israel. Konflik yang dimulai ketika Israel berdiri pada 14 Mei 1948. Yahudi menganggap bahwa tanah Palestina merupakan tanah yang dijanjikan sehingga Yahudi berhak untuk menempati tanah yang ada di Negara tersebut. Sedangkan Muslim menganggap bahwa Palestina merupakan tanah dimana mereka lahir dan berkembang di daerah tersebut. Polemik ini seakan tidak ada ujung penyelesaiannya mulai dari tahun 1967-2010. Keberlanjutan konflik ini masih terjadi namun perkembangan internasional bergeser ke arah konflik Yaman (Muti'ah: 1998).

Konflik ini semakin meruncing ketika adanya konflik Yaman sedang 'booming'. Yaman yang sesuai undang - undang internasional dibela oleh Arab Saudi sedangkan Pemberontak yang ada di Yaman dibela oleh Iran. Sebenarnya konflik bersenjata di Yaman yang semakin besar adalah hasil dari gejolak sebelumnya yang terjadi selama bertahun-tahun. Konflik ini jika dicari awal mulanya adalah dampak dari gelombang Arab Spring yang terjadi pada akhir 2010. Gelombang Arab Spring yang melanda negaranegara Timur Tengah bermula dari ketidakpuasan warga negara-negara Arab terhadap pemerintah mereka. Gelombang protes yang pertama pecah di Tunisia pada Desember 2010, kemudian menyebar ke negara Arab lainnya.

Ideologi dari pemerintahan yang berkuasa yaitu Mansour Hadi yang dilindungi oleh Arab Saudi kemudian berlawanan dengan Houthi yang dilindungi oleh Iran. Sedangkan untuk Yahudi selalu berlawanan dengan Islam apapun ideologi Islam tersebut. Hal ini dikarenakan sentimen dari tiap agama terlalu kuat sehingga membuat konflik terus berlanjut hingga sekarang. Dalam tingkat Negara, konflik sunni-syiah juga terjadi pada beberapa Negara seperti Iraq, Iran, Arab Saudi dan Libanon. Ada yang berupa peminggiran kelompok syi'ah terutama di Iraq, Arab Saudi dan ada pula peminggiran kepada kelompok sunni terutama di Iran, atau dibentuk rotasi kekuasaan yang dilakukan di Libanon dimana kelompok keagamaan satu sama lain saling membangun aliansi politik.

\section{KESIMPULAN}

Kekayaan sumber daya alam terutama sumber daya minyak yang ada di Kawasan Timur Tengah akan selalu menjadi sumber konflik di Timur Tengah. Sekitar $66 \%$ produksi minyak dunia itu berada di Kawasan Timur Tengah. Perbedaan ideologi, sosial budaya yang ada di negara dan masyarakat Timur Tengah juga menjadi faktor pemicu konflik berkepanjangan. Jadi, wilayah Timur Tengah bisa dikatakan adalah negara yang dianugrah potensi sumber daya yang melimpah sekaligus itu juga menjadi sumber konflik yang berkepanjangan. Keberagaman agama dan suku menjadikan wilayah ini kaya dengan pemikiran-pemikiran, sekaligus juga menjadi sumber-sumber konflik.

Konflik di Kawasan ini tidak akan pernah selesai jika negara-negara besar dunia masih memiliki kepentingan yang besar terhadap Kawasan Timur Tengah. Konsekuensinya, aturan PBB dan mediasi 
yang dilakukan oleh pihak-pihak yang berkeinginan terciptanya perdamaian di Kawasan Timur Tengah tidak akan pernah menemukan titik terang.

\section{SARAN}

Penulis menyadari masih banyak kekurangan dalam penelitian ini terkait data dan konflik yang masih belum mampu diselesaikan. Maka penelitian lanjut terkait isu ini sangat direkomendasi untuk diteliti sebagai penambah khasanah keilmuan.

\section{DAFTAR PUSTAKA}

[1] Fawcett, Louise, 2018, Virtual Issue: The Middle East in International Affairs, International Affairs Virtual Issue, July 2018.

[2] Galtung, Johan, 1996, Peace by Peaceful Means: Peace and Conflict, Development and Civilization, London: Sage Publication.

[3] ] Galtung, Johan, 2009, Theories of Conflict: Definitions, Dimensions, Negations, Formations, diakses dari (https://www.transcend.org/files/Galtung_Book_Theories_Of_Conflict_single.pdf)

[4] Irani, George E, 1999, Islam Mediation Technique for Middle East Conflicts, Middle East Review of International Affairs, Vol. 3, No. 2.

[5] Jemadu, Aleksius, 2017, Politik Global dalam Teori dan Praktik Edisi 3, Yogyakarta: Suluh Media.

[6] Jemadu, Aleksius, 2008, Politik Global dalam Teori dan Praktik, Yogyakarta: Graha Ilmu.

[7] Mansbach, Richard W \& Kirsten L. Rafferty, 2008, Introduction to Global Politics, London: Routledge.

[8] Ruslin, Ismah Tita, 2013, Memetakan Konflik di Timur Tengah (Tinjauan Geografi Politik), Jurnal Politik Profetik, Vol. 1,No. 1.

[9] Sahide, Ahmad, 2013, Suku Kurdi dan Potensi Konfik di Timur Tengah, Jurnal Hubungan Internasional, Vol.2, No.2, Oktober 2013.

[10] Surwandono, 2013, Relasi antara Tingkat Konflik di Dunia Islam dengan Setting Geografi Politik: Studi Kasus Konflik di Kawasan Timur Tengah, Jurnal Hubungan Internasional, Vol. 2, No. 1.

[11] Tan, Kim Hua and Alirupendi Perudin, 2019, The Geopolitical Factor in the Syirian Civil War: A Corpus-Based Thematic Analysis, Sage Open Journal.

[12] Yenigun, Cuneyt, 2016, Conflict Resolutionfor The Middle East: Sectarian Rapprochement, Vol. 3, No. 2. 
[13] https://www.hrw.org/world-report/2019/country-chapters/israel/palestine

[14] https://www.theguardian.com/world/2019/jun/20/yemen-civil-war-the-conflict-explained 